\title{
FOUR YEARS AFTER THE CATASTROPHE, ARE EDUCATIONAL INSTITUTIONS IN THE REGION OF MURCIA IN SPAIN PREPARED FOR THE NEXT SEISMIC DISASTER?
}

\author{
Sophie Mendizabal \\ Dirección de Gestión de Riesgos, Municipalidad de Santa Fe de la Vera Cruz, Argentina.
}

\begin{abstract}
A magnitude 6.0 or more earthquake is expected on the Alhama de Murcia fault, the most active in the region of Murcia, located in the south-eastern Spain. On May 11 $1^{\text {th }}$ 2011, within one hour and 42 minutes period, a magnitude 4.5 and a magnitude 5.1 earthquakes shake the towns of Lorca and Totana, killing nine people and injuring 330. However, four years after the catastrophe, these towns do not seem to be prepared to face a moderate earthquake. All elements are gathered to result in a disaster, i.e. a surface geomorphology conducive for site effects, constructions which do not comply the earthquake-resistant requirements and a lack of knowledge from the population about the seismic risk. This study proposes an analysis of the level of vulnerability of educational institutions against the seismic risk in Lorca and Totana based on creating a vulnerability index which considers social and structural risk factors. As well as a series of mitigation measures proposals to face the next major seismic disaster.
\end{abstract}

Key words: index; earthquake; vulnerability; educational institution; Alhama de Murcia fault.

\section{CUATRO AÑOS DESPUÉS DE LA CATÁSTROFE, ¿ESTÁN LOS CENTROS EDUCACIONALES DE LA REGIÓN DE MURCIA EN ESPAÑA PREPARADOS PARA EL PRÓXIMO DESASTRE SÍSMICO?}

\section{RESUMEN}

Un terremoto de magnitud 6.0 o más está esperado en la falla Alhama de Murcia, la más activa de la región de Murcia, localizada en el sureste de España. El 11 de Mayo de 2011, en un intervalo de una hora y 42 minutos, dos terremotos de magnitud 4.5 y 5.1 sacuden las ciudades de Lorca y Totana, resultando en nueve fatalidades y 330 heridos. Sin embargo, cuatro años después de la catástrofe, estas ciudades no parecen estar preparadas a hacer frente a un terremoto de magnitud moderada. Todos los factores están combinados para terminar en una catástrofe es decir, una superficie geomorfológica que favorece los efectos de sitio, construcciones que no cumplen con las normas parasísmicas y la falta de conocimiento sobre el riesgo sísmico por parte de la población. Este estudio propone un análisis del nivel de vulnerabilidad de los centros educacionales contra el riesgo sísmico en Lorca y Totana basado en la creación de un índice de vulnerabilidad considerando los factores de riesgo sociales y estructurales. Además propone una serie de medidas de mitigación para hacer frente al próximo desastre sísmico mayor.

Palabras clave: índice; terremoto; vulnerabilidad; centro educacional; falla Alhama de Murcia.

\footnotetext{
${ }^{1}$ Dirección de Gestión de Riesgos, Municipalidad de Santa Fe de la Vera Cruz, Argentina. E-mail: sophie.geomatic@gmail.com
}

Fecha de recepción: 08 de enero de 2020. Fecha de aceptación: 29 de enero de 2020

Papeles de Geografía, 65 (2019), 155-174 


\section{INTRODUCTION}

At European level, earthquakes, i.e. a "sudden movement of a block of the Earth's crust along a geological fault and associated ground shaking" (GUHA-SAPIR et al., 2016), represent $0.53 \%$ of total number of victims of natural disasters. Notwithstanding, according to EMDAT data, between 2004 and 2014, earthquakes are among the hazards that cause the most economical damage with 18.2 billion euros, after heat-waves and floods.

In Spain, the seismic activity is not comparable with other countries where is much higher, however it still represents a high risk in the Mediterranean area. In previous centuries, Spain has experienced many earthquakes with a significant magnitude and intensity. The seismic activity is spread over three main regions. To the north-east on the Pyrenean chain, to the south in the region of Almeria and to the south-east in the region of Murcia. Among these, the region of Murcia knows the most active seismicity due to the presence of the active Alhama de Murcia fault (Figure $1)$.

FIGURA 1

Spanish regions with the highest seismic activity

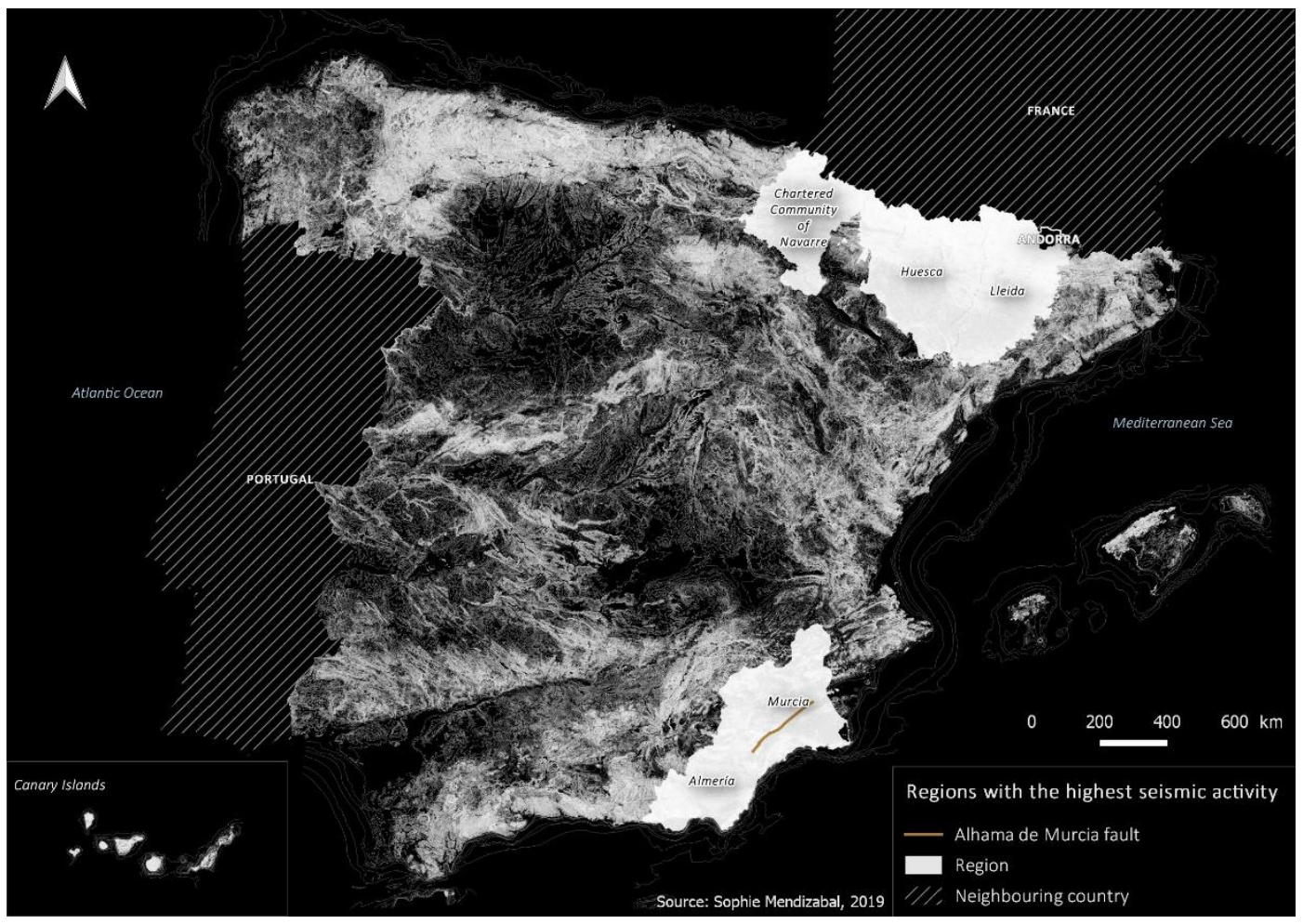

Source: Data from IGN España. Creation: Sophie Mendizabal, 2019

The region of Murcia has experienced four major earthquakes that have affected different municipalities, i.e. Lorca in 1674, Las Torres de Cotillas in 1911, Cehegín in 1948. The latest one occurred on May 11th 2011 and caused 172 million euros of economic damage, nine deadly victims and 330 injured. Thereby, one of the most important challenges for the region of Murcia is the mitigation of the vulnerability of its inhabitants. Thus, the mitigation measures is a key factor in the overall reduction of seismic risk.

Lorca and Totana are located $19 \mathrm{~km}$ away from each other and on the Alhama de Murcia fault. The rugged terrain of La Peña Rubia and La Tercia mounts characterizes this area. The rise of the two mounts is located less than $1 \mathrm{~km}$ from the town of Lorca and $6 \mathrm{~km}$ from the town of Totana (Figure 2) and belong to the one of the main geodynamic processes that generate strong seismic activity in Spain. The marked relief are favorable to site effects. In fact, when the seismic waves reach the surface of the ground, they are trapped and thus, their amplitude and acceleration become stronger. The faults of this region produce low and moderate magnitude earthquakes. 
Nevertheless, they can cause significant human and economic damage to urbanized areas located a few kilometers from the epicenter. This was the case, on May 11th 2011, within one hour and 42 minutes period, for the two earthquakes of magnitude 4.5 and intensity VI for the first and magnitude 5.1 and intensity VII for the second on the Alhama de Murcia fault, whose epicenter was located $4 \mathrm{~km}$ deep under the La Tercia mount and $5 \mathrm{~km}$ north of Lorca.

FIGURA 2

Geologic area around the towns of Lorca and Totana

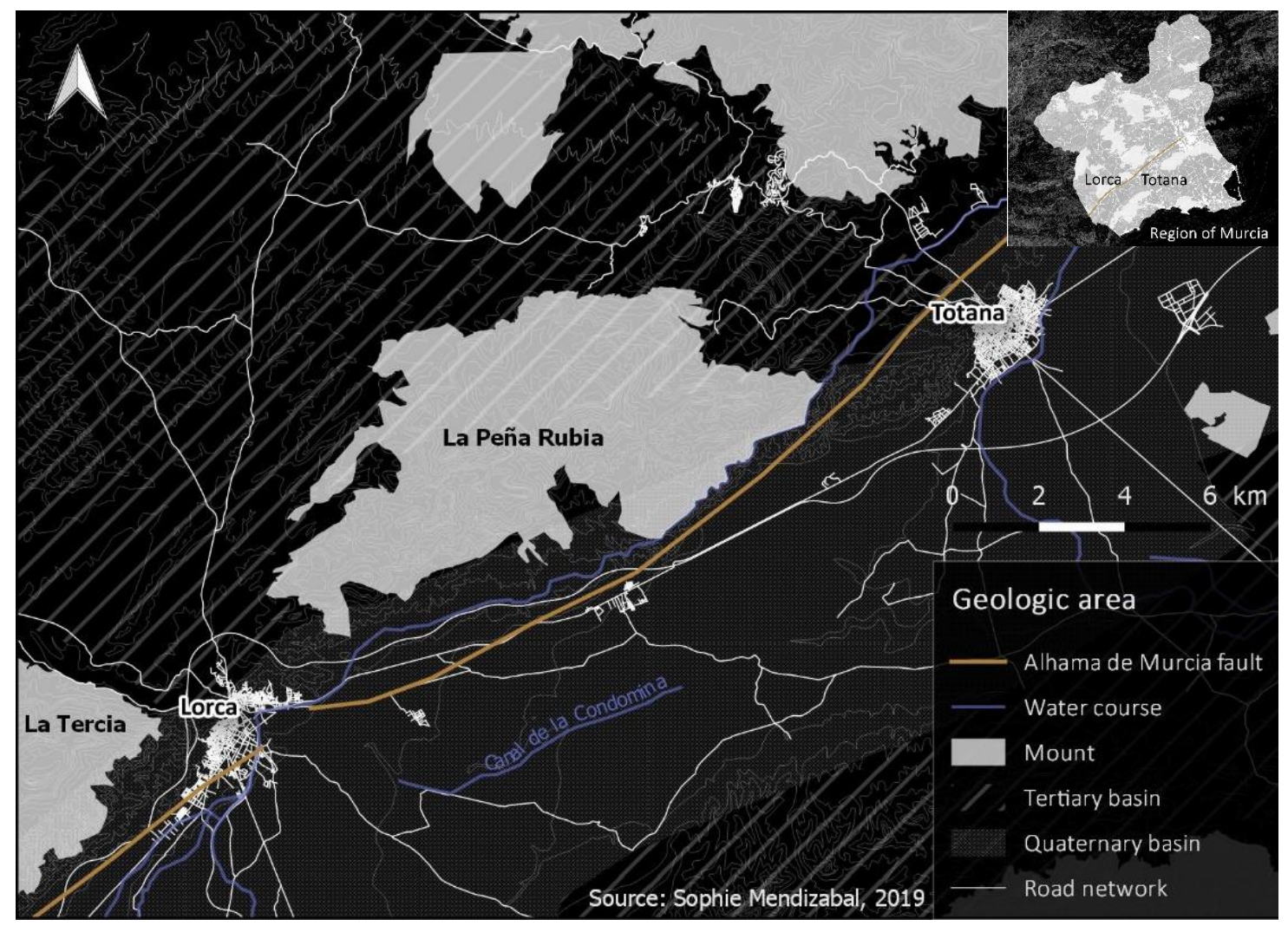

Source: Data from IGN España. Creation: Sophie Mendizabal, 2019

In the case of Lorca, each neighborhood felt different degree of intensity according the European macroseismic scale (EMS 98). The closest neighborhoods to the epicenter are those with a higher intensity, i.e. VII degree felt in Fuerzas Armadas, Corazón de María, Los ÁngelesApolonia and San Cristóbal. However the neighborhood La Viña is a particular case because it was more away from the epicenter but is where an entire building collapsed. A correlation is made linking the intensity felt in each neighborhood, the hardness of the ground (BENITO OTERINO et al., 2012) and the quantity of buildings damaged. La Viña is one of the oldest neighborhoods and is located on a ground mainly composed of sedimentary deposits (hardness of type III). The most remote neighborhoods of epicenter felt a minor intensity, i.e. V and VI (Figure 3). Unfortunately, any data exists for the town of Totana. 
FIGURA 3

Intensity felt and hardness of the ground in each neighborhood of Lorca on May 11th 2011

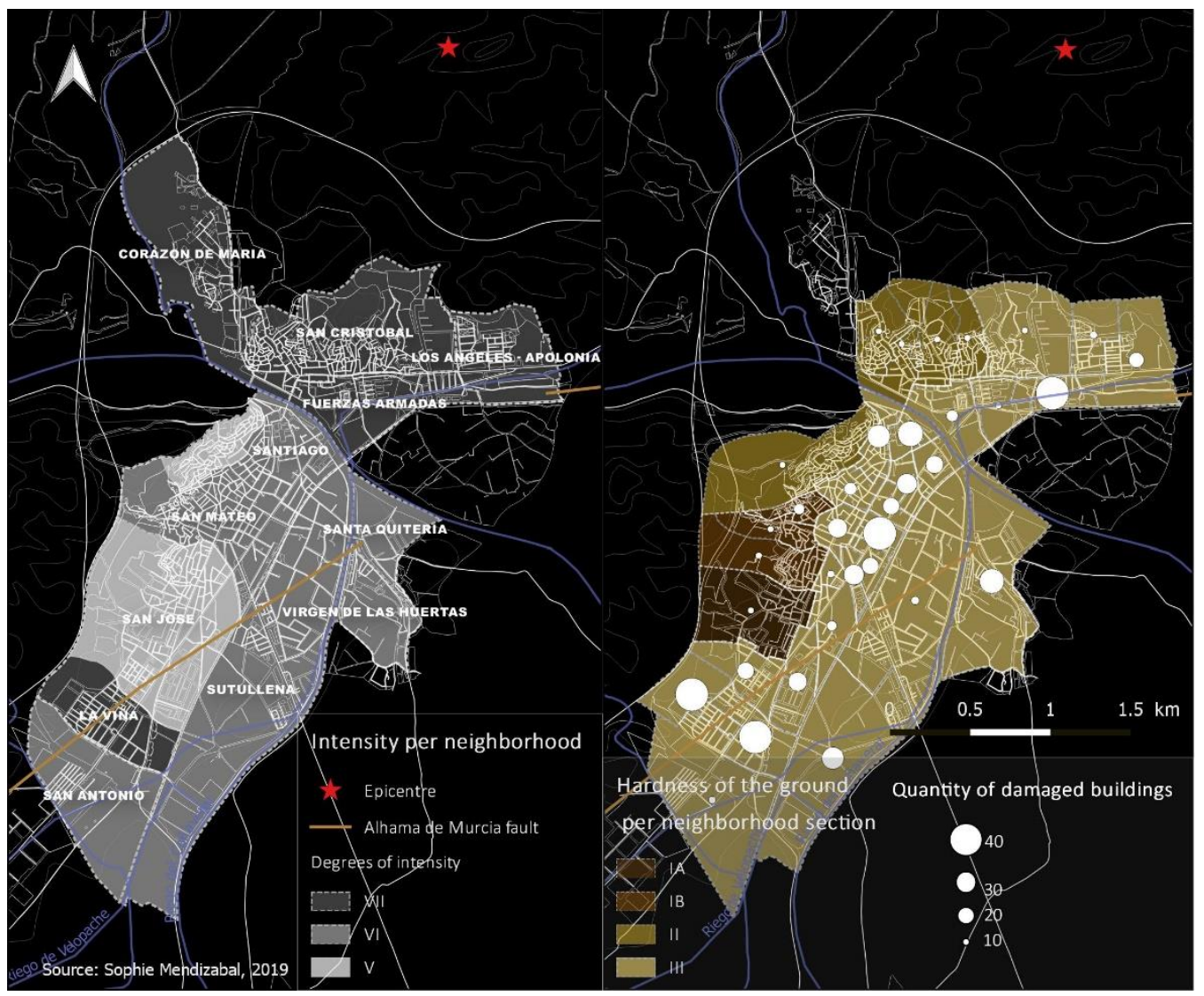

Source: Sophie Mendizabal, 2019

Nevertheless, this fault would have the capacity to produce a magnitude 6.0 or more earthquakes (CAPOTE et al., 2011). Furthermore, the sedimentary basin, where the towns of Lorca and Totana are located, is composed of deposits of alluvium and colluvium. It corresponds on a type of soil conducive to site effects during a catastrophe because it amplifies the impact of seismic waves and as a result, the vibrations felt in the towns are more intense (VISSERS et al., 2011; SALCEDO HERNÁNDEZ et al., 2012). The two May 2011 earthquakes had a high Peak Ground Acceleration (PGA) i.e. 0.37g for the largest. However, the research results prior to this event predicted a maximum value PGA reaching $0.16 \mathrm{~g}$ with a probability of excess of $10 \%$ in 50 years. It means that Lorca and Totana are not immune to an earthquake that could cause significant human and economic damage. The inhabitants must be able to respond in the event of a major earthquake.

The data collection for this work was made in 2015 so the whole analysis is based on the situation of this year to implement a comparative study in a few years. The data about the vulnerability of the institutions obtained in this work are available at https://doi.pangaea.de/10.1594/PANGAEA.909868. The study is carried out with the fundamental purpose of determining if the educational institutions are able to cope with a new seismic disaster and thus, analyze the level of preparedness in Lorca, a town that has experienced an earthquake in 2011, and Totana which did not since 1921. Lorca and Totana are small urban cores, so the project considers all public and private educational institutions of all levels, from nursery to higher educational level.

Before developing this research work, it is necessary to define the main concepts pursued. Firstly, the seismic risk represents the combination of the earthquake with the human and economic implications, i.e. the educational institutions, and their vulnerability. In fact, the latter 
concept is characteristic of the reaction dysfunction of the institutions exposed to seismic risk.

\section{A METHOD OF ANALYSIS OF THE VULNERABILITY OF EDUCATIONAL INSTITUTIONS}

\subsection{HYPOTHESES}

The experience of teachers and directors of educational institutions is a very important factor in the analysis of the level of vulnerability because it helps to develop knowledge and skills from past events. The director's experience can be considered as a test. If he has experienced the earthquake of 2011, it is assumed that the system of prevention in his institution and the level of preparedness of teachers and students are of good quality, and from the overall perspective, the institution presents a low vulnerability. A low vulnerability means that the institutions are able to cope with a disaster. On the contrary, if they have a high vulnerability, this means that since the earthquake of May 11, 2011, their level of preparedness has not improved and that the authorities have not adopted the best means of communication to inform the institutions about the seismic risk present in the region.

Structurally, the resistance of these constructions during an earthquake varies according to earthquake resistant-requirements (BSSC, 2006). The intensity VII felt during the earthquake of 2011 is characterized by the difficulty to stand up, especially on the upper floors. In construction projects, the number of floors is recommended according to the PGA and the type of construction. However, we suppose that the directors do not know which materials were used for the construction, so we have concentrated the structural study on the number of classrooms, the seismic standards, the subscription to an insurance and if the data were saved on an external support.

\subsection{CHARACTERISTICS OF EDUCATIONAL INSTITUTIONS}

Two main reasons guided the choice of these two towns: their proximity and similarities mentioned above and especially the absence of study of the level of preparedness and perception of seismic risk in educational institutions in Lorca and Totana. This was confirmed after many searches and by Sofía González López, head of the Civil Protection of the region of Murcia, during an interview in her office.

Furthermore, the choice to concentrate the research on these institutions was made considering that students play both the role of information receptacle during simulations at school, but also the role of informant with their family. This educational approach would be a solution for newcomers and foreigners thanks to the information given to their children attending schools in Lorca (10 800 Ecuadorians and North Africans, constituting 11.6\% of the total population) and Totana (6 567 foreigners, i.e. $20.7 \%$ of the total population).

After referencing all institutions on a map of Lorca and Totana, a first field trip was conducted to find out which institutions are still active and which are not. Thus, eight of them were removed from the list of institutions to be investigated, including three in Lorca and five in Totana (Figure 4). 
FIGURA 4

Localization of educational institutions in Lorca and Totana

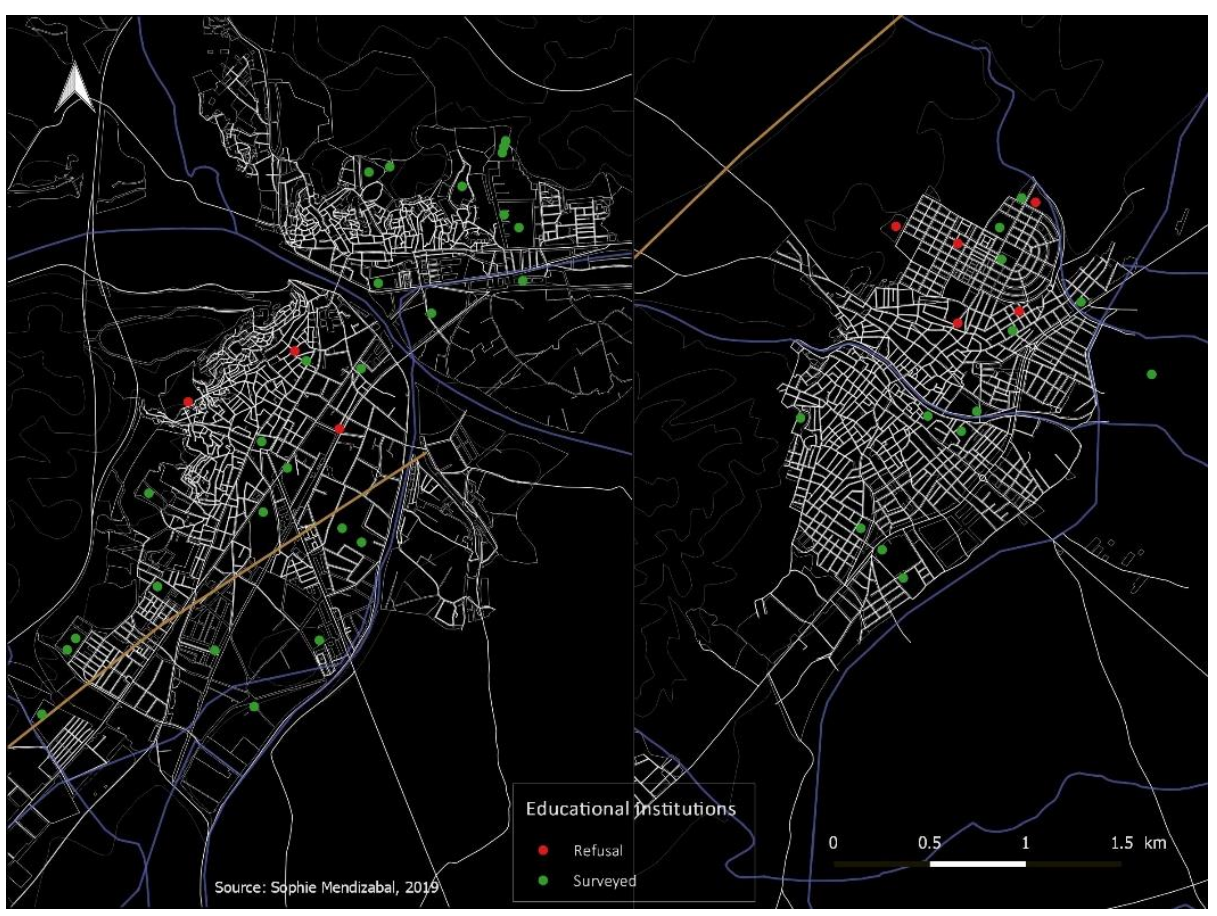

Source: Sophie Mendizabal, 2019

At the beginning of this study, the total of the sample amounted to 47 educational institutions for the towns of Lorca and Totana (Table 1). However, some institutions refused to participate. In the case of Lorca, $89.65 \%$ were interviewed and $72.22 \%$ for the town of Totana. This percentage is considered sufficiently representative of all institutions.

TABLE 1

Level of study of the educational institutions in the sample in Lorca and Totana

\begin{tabular}{|c|c|c|c|c|c|c|}
\hline \multirow[t]{2}{*}{ Types of institutions } & \multicolumn{2}{|c|}{$\begin{array}{l}\text { Initial number of } \\
\text { institutions }\end{array}$} & \multicolumn{2}{|c|}{$\begin{array}{c}\text { Number of institutions } \\
\text { interviewed }\end{array}$} & \multicolumn{2}{|c|}{$\begin{array}{c}\text { Percentage of } \\
\text { institutions } \\
\text { interviewed }\end{array}$} \\
\hline & Lorca & Totana & Lorca & Totana & Lorca & Totana \\
\hline Nursery & 1 & 2 & 1 & 2 & 3.85 & 15.39 \\
\hline Kindergarten & 4 & 5 & 3 & 2 & 11.53 & 15.39 \\
\hline Primary school & 13 & 8 & 12 & 7 & 46.15 & 53.93 \\
\hline College & 6 & 3 & 6 & 2 & 23.07 & 15.39 \\
\hline Training center & 1 & 0 & 1 & 0 & 3.85 & 0 \\
\hline Special education school & 3 & 0 & 2 & 0 & 7.70 & 0 \\
\hline University & 1 & 0 & 1 & 0 & 3.85 & 0 \\
\hline Total & 29 & 18 & 26 & 13 & 100 & 100 \\
\hline
\end{tabular}

The overrepresentation of primary schools is explained by the small and medium capacity of these institutions. They count every year between 140 and 680 students, and between 23 and 52 teachers (results of the survey) knowing that the total of children amounts to 5015 , according to the data of the National Statistics Institute, thus the number of infrastructures is greater.

\subsection{FIELD INVESTIGATION}

It was necessary to think ahead of each step that punctuated this study, from the elaboration of the questionnaire to the method of data processing and analysis. The questionnaire was written using Sphinx, a survey and statistical data analysis software, and divided into four main sections: the structural description of the institution, the experience and knowledge about the seismic risk of the director, the prevention methods implemented within the institution to respond to an 
earthquake, and the director's knowledge about how to behave during an earthquake. A final part was dedicated to the suggestions that respondents can offer for improving the prevention and protection system or in general, reducing the vulnerability of their institution. During the test phase, it turned out that beyond 40 questions, respondents began to get impatient. As a result, the number of questions has been revised downwards to an approximate response time of five minutes. It was considered before the beginning of the survey because directors are often very busy and cannot give a long time to interviews.

The choice of questions was largely based on the method of processing. Indeed, these must be treated in a simple and fast way. The questionnaire is composed of 27 closed questions, whose 20 are single-choice, binary or Boolean, and seven multiple-choice questions. The aim is to keep control over the maximum number of possible answers while leaving some freedom to the respondent. In this way, more precise information is obtained on the questions. Another type of question appears in the questionnaire, the numeric-type question. Finally, some open questions were introduced in the questionnaire in order to collect interesting and more precise answers.

\subsection{MEASURE THE VULNERABILITY: GLOBAL INDEX OF VULNERABILITY TO EARTHQUAKE}

For the processing and the statistical analysis of the data obtained during the field work, we initially took inspiration from the MOVISS method. It was designed by the Alpine Center for Natural Hazards and Risks Prevention in order to access social vulnerability to earthquakes in France. It has been applied for the first time in the city of Grenoble, France, because the seismicity of this sector is weak but the tectonic context is favorable to the occurrence of earthquakes of magnitude 6.0. To do this, a global index was created, namely, the Global Index of Vulnerability to Earthquake (GIVE), including human and structural vulnerabilities.

The global index results from the weighted average of the vulnerability indexes attributed to each variable. The vulnerability indexes are between 0 and 3 , where 0 represents a very low level of vulnerability or even zero, 1 corresponds to a low level of vulnerability, 2 represents a medium vulnerability and 3 means a high vulnerability. It was decided to assign a higher weight to the variables according to their importance. The coefficient has been multiplied by two for the most important variables, the human vulnerability. The calculation of the GIVE is in the following form:

$$
\text { GIVE }=\frac{[(\text { Human Vulnerability Index } * 2)+(\text { Structural Vulnerability Index })]}{3}
$$

The results of the GIVE have been discretized into three classes:

- a low vulnerability and a high level of preparedness if $0 \leq \mathrm{GIVE} \leq 1$;

- a moderate vulnerability and a moderate level of preparedness if $1<\mathrm{GIVE} \leq 2$;

- and a high vulnerability and a low level of preparedness if $2<\mathrm{GIVE} \leq 3$.

For the Human Vulnerability Index, the variables were classified into three main themes: seismic hazard preparedness and prevention, knowledge and experience about earthquake, and how to behave during an earthquake (Table 2). For reasons of space these two tables are not comprehensive but presents the most important risk factors. 
TABLE 2

Indexes assigned to each variable composing the Human Vulnerability Index

\begin{tabular}{|c|c|c|}
\hline Variable & Answer & Index \\
\hline \multicolumn{3}{|c|}{ PREPAREDNESS/PREVENTION } \\
\hline \multirow[t]{3}{*}{ Presence of an emergency plan } & Yes & 0 \\
\hline & No & 3 \\
\hline & Do not know & 3 \\
\hline \multirow{3}{*}{ Presence of an evacuation plan } & Yes & 0 \\
\hline & No & 3 \\
\hline & Do not know & 3 \\
\hline \multirow[t]{2}{*}{ Teachers trained in security measures } & Yes & 0 \\
\hline & No & 3 \\
\hline \multirow[t]{2}{*}{ Designation of one or more responsible in case of emergency } & Yes & 0 \\
\hline & No & 3 \\
\hline \multirow[t]{2}{*}{ Simulation exercise } & Yes & 0 \\
\hline & No & 3 \\
\hline \multirow[t]{2}{*}{ Survival kit } & Yes & 0 \\
\hline & No & 3 \\
\hline \multicolumn{3}{|c|}{ KNOWLEDGE/EXPERIENCE } \\
\hline \multirow[t]{2}{*}{ The director has already experienced an earthquake } & Yes & 0 \\
\hline & No & 3 \\
\hline \multirow[t]{2}{*}{ The director knows that Lorca/Totana is in a high risk area } & Yes & 0 \\
\hline & No & 3 \\
\hline \multirow{2}{*}{$\begin{array}{l}\text { The director knows if refuge areas exist and knows where to locate } \\
\text { them }\end{array}$} & Yes & 0 \\
\hline & No & 3 \\
\hline \multicolumn{3}{|c|}{ BEHAVIOR DURING AN EARTHQUAKE } \\
\hline \multirow[t]{6}{*}{ Best behavior } & Go out running & $*$ \\
\hline & Sit down and wait & \\
\hline & Take refuge under a table & \\
\hline & Stand in the frame of a door & \\
\hline & Close the gas network & \\
\hline & Do not know & \\
\hline \multirow[t]{6}{*}{ Evacuate the building } & Walk in the center of the hallway & $*$ \\
\hline & Take the elevator & \\
\hline & Go down the stairs & \\
\hline & Stay confined in the room & \\
\hline & Evacuate a few minutes after shaking & \\
\hline & Do not know & \\
\hline \multirow[t]{7}{*}{ Outside } & Stay in the street and wait for help & $* *$ \\
\hline & Go home & \\
\hline & Go to a refuge area & \\
\hline & Follow the designated officer & \\
\hline & Take refuge in a sheltered place & \\
\hline & Return to the building & \\
\hline & Do not know & \\
\hline \multirow[t]{5}{*}{ On a refuge area } & Identify present people & $* * *$ \\
\hline & Report missing people & \\
\hline & Listen to the instructions by radio & \\
\hline & Help people in difficulty & \\
\hline & Do not know & \\
\hline
\end{tabular}

* 0 for three correct answers, 1 for two correct answers, 2 for a correct answer, 2 for correct and wrong answers, 3 if a wrong answer or more and if do not know/answer.

** 0 for two correct answers, 1 for a correct answer, 2 for correct and wrong answers, 3 if a wrong answer or more and if do not know/answer.

*** 0 if all the answers checked, 1 for three answers checked, 2 for two answers checked, 3 for a checked answer or if do not know/answer.

For the Structural Vulnerability Index, the variables are as follows (Table 3). 
TABLE 3

Indexes assigned to each variable composing the Structural Vulnerability Index

\begin{tabular}{lll}
\hline Variable & Answer & Index \\
\hline Number of classrooms & $1-14$ & 0 \\
& $15-27$ & 1 \\
& $28-40$ & 2 \\
& $41-54$ & 3 \\
\hline Seismic standards & Yes & 0 \\
& No & 3 \\
\hline Subscription to an insurance & Do not know & 3 \\
& Yes & 0 \\
& No & 3 \\
Furniture fixed to the walls & Do not know & 3 \\
& Yes & 0 \\
& Not all & 2 \\
\hline Data saved on an external hard drive & No & 3 \\
\hline
\end{tabular}

It is assumed that an institution is more vulnerable if the number of classrooms is high because it implies that the designated responsible have more classrooms to check urgently. It increases the time of evacuation and secure students.

\section{THE RESULTS OF THE QUESTIONNAIRES}

\subsection{THE STRUCTURE OF EDUCATIONAL INSTITUTIONS}

Three closed questions were posed to the directors regarding the structure of the institution (Table 4).

TABLE 4

Percentage distribution of answers to closed unique questions about the educational institutions

\begin{tabular}{llll}
\hline Questions & Yes & No & Do not know \\
\hline 7. Is your institution built to seismic standards (NCSE-02 standard)? & 51,28 & 38,46 & 10,26 \\
\hline 8. If no, do you think it is protected against seismic risk? & 40 & 35 & 25 \\
\hline $\begin{array}{l}\text { 11. After the earthquake of May 11, 2011, do you know if an inspection and/or } \\
\text { a diagnosis of your institution were made? }\end{array}$ & 66,67 & 28,20 & 5,13 \\
\hline
\end{tabular}

Just over half of the directors interviewed, i.e. $51.28 \%$, responded that their institution was built to earthquake-resistant standards. Thus they obtained an index 0 , unlike the other institutions which were given an index 3 because indeed, if the institution is not built to the seismic standards $(38.46 \%)$ or if the director does not have this information is not available $(10.26 \%)$, it is assumed that it adds a degree of vulnerability to an earthquake. Of the non-standard buildings, $40 \%$ of directors believe they are protected against seismic risk. According to three directors of Lorca primary schools "our institution, even if it is not built according to the standards, it resisted the last earthquake", "the structure and the pillars have been strengthened" and "my school was built on rocky ground".

The last closed question concerning the completion of a structural diagnosis shows that $66.67 \%$ of the institutions were inspected by experts, against $28.20 \%$ who did not do so. This last percentage is very high when one knows that after the passage of an earthquake, the structures can be strongly damaged. The cracks do not necessarily appear on the facades, yet the foundations can be deformed because of the action of the ground and therefore threaten to collapse at any time and put the lives of its occupants in danger. The remaining 5.13\% represents directors who were not present at their current institution and therefore were not informed of past diagnoses. 
TABLE 5

Percentage distribution of answers to question 12 regarding the work undertaken following the May 11, 2011 earthquake

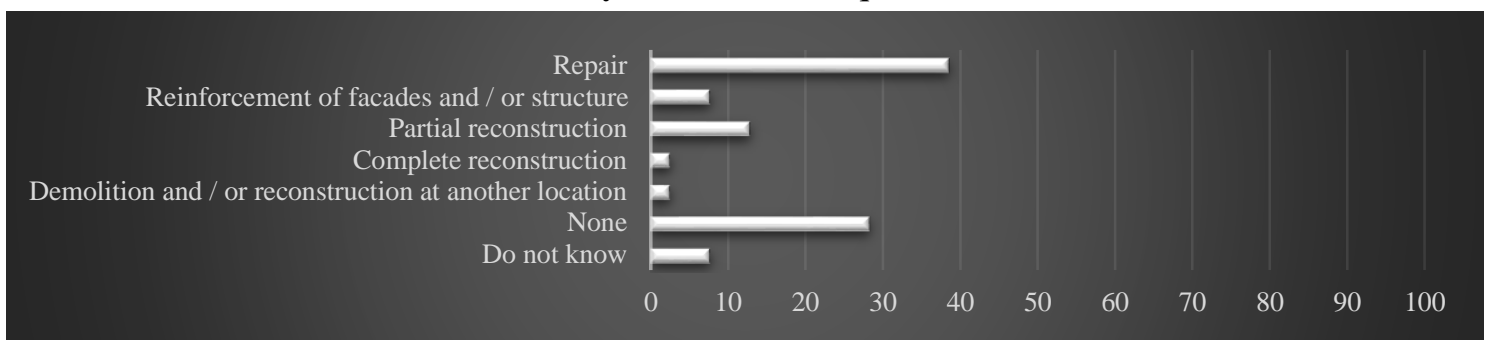

The bar graph above indicates that the majority of institutions completed only repairs after the 2011 earthquake with a rate of $38.48 \%$ (Table 5). For $28.20 \%$ of the total institutions, no repair work was done. Note that this percentage corresponds to institutions that did not carry out a diagnosis of their structure, except for two of them who repaired cracks in the facades. $12.82 \%$ of the institutions rebuilt part of their construction, for example a classroom, a canteen or replaced the damaged roof or partially destroyed by a roof respecting the seismic standards. As for facade and structure reinforcement work, only $7.69 \%$ of institutions are concerned. Complete reconstructions (2.56\%) and demolitions (2.56\%) do not form the majority. Directors who do not know if any work has been done (7.69\%) are those who were not present at their current institution or who started their job after the disaster.

These types of repairs are explained by the level of damage that institutions have experienced. The damage was classified into four levels (Table 6).

TABLE 6

Percentage distribution of answers to question 10 regarding the level of damage experienced by educational institutions during the May 11, 2011 earthquake

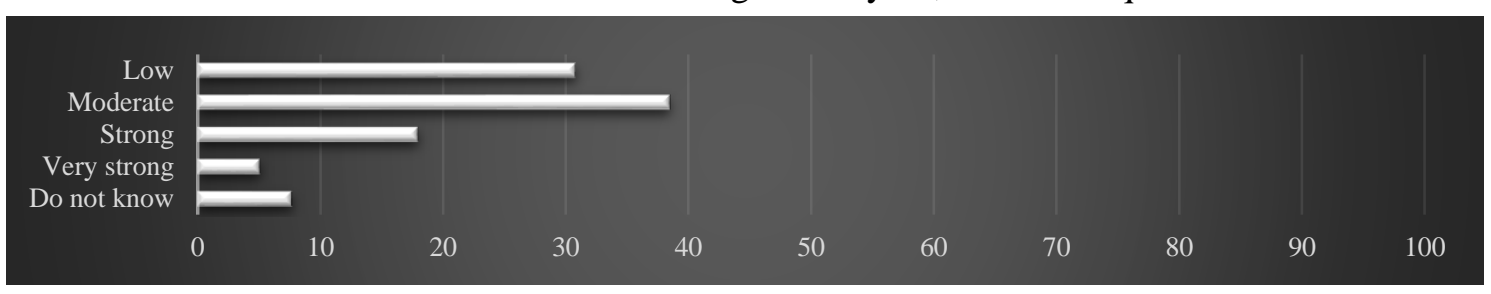

The low level, suffered by $30.77 \%$ of the institutions, is characterized by the fall and the displacement of objects. The moderate level, experienced by $38.47 \%$, corresponds to the opening of superficial cracks in the walls and the fall of pieces coming from facades such as parapets. Then, $17.95 \%$ of educational institutions have suffered heavy damage such as the partial destruction of their structure or the opening of deep cracks in the walls. Finally, 5.12\% is the percentage of institutions that have been heavily damaged and have undertaken demolition and complete reconstruction, and $7.69 \%$ do not know the level of damage during the earthquake.

\subsection{THE EXPERIENCE AND KNOWLEDGE OF DIRECTORS ABOUT THE SEISMIC RISK}

More than half of the directors have experienced another earthquake than in 2011. The most frequently mentioned are those of February 2015, one with a magnitude of 2.3 and the other with a magnitude 5.2. We note that all the dates mentioned correspond to moderate magnitude earthquakes. Below are the answers to the closed questions asked (Table 7). 
TABLE 7

Percentage distribution of answers to closed questions regarding directors' experience and knowledge about seismic risk

\begin{tabular}{llll}
\hline Questions & Yes & No & Do not know \\
\hline 15. Is your institution located in a high-risk area? & 43.59 & 51.29 & 5.12 \\
\hline $\begin{array}{l}\text { 16. Are you concerned that another earthquake, of moderate to high } \\
\text { magnitude, may occur on the Alhama de Murcia fault? }\end{array}$ & 89.75 & 10.25 & 0 \\
\hline 17. Would it damage the institution? & 71.80 & 15.38 & 12.82 \\
\hline
\end{tabular}

Question 15 allows to know if the directors have a good perception of the seismic risk or in return, if the authorities and the media have informed them well about this hazard. A simple question can reveal crucial information. One might wonder whether the directors understood the question correctly or confused with the seismic activity of the region, which is moderated from a planetary point of view. Notwithstanding, 51.29\% of directors think they are not in high-risk area and 5.12\% could not answer. Undoubtedly, the towns of Lorca and Totana are on the passage of the active Alhama de Murcia fault and therefore, in a high risk zone. However, even though $43.59 \%$ think they are in a high risk zone, this percentage is still insufficient.

Regarding the question 16, it shows that some directors are worried that another moderate or even high magnitude earthquake to occur on the fault, while others, on the contrary, are not worried. $89.75 \%$ are worried. This percentage can be correlated with the results to the previous questions regarding seismic standards, diagnosis and work, and level of damage (Table 8).

TABLE 8

Cross-tabulations linking directors' answers with the structural vulnerability

\begin{tabular}{l|llll}
\cline { 2 - 5 } & \multicolumn{2}{|l}{ Structure diagnosis } & & Do not know \\
\hline The director is worried & Yes & No & Total \\
\hline Yes & $\mathbf{2 3}$ & 10 & 2 & 35 \\
\hline No & 3 & 1 & 0 & 4 \\
\hline Total & 26 & 11 & 2 & 39 \\
\hline
\end{tabular}

\begin{tabular}{|c|c|c|c|c|}
\hline & \multicolumn{4}{|c|}{ Construction with seismic standards } \\
\hline The director is worried & Yes & No & Do not know & Total \\
\hline Yes & 19 & 13 & 3 & 35 \\
\hline No & 1 & 2 & 1 & 4 \\
\hline Total & 20 & 15 & 4 & 39 \\
\hline
\end{tabular}

\begin{tabular}{l|llllll}
\cline { 2 - 7 } & Execution of works & & & Dot \\
\hline $\begin{array}{l}\text { The director is } \\
\text { worried }\end{array}$ & $\begin{array}{l}\text { None/R } \\
\text { epair }\end{array}$ & Reinforcement & $\begin{array}{l}\text { Partial } \\
\text { reconstruction }\end{array}$ & $\begin{array}{l}\text { Complete } \\
\text { reconstruction } \\
\text { and demolition }\end{array}$ & $\begin{array}{l}\text { Do } \\
\text { know }\end{array}$ & Total \\
\hline Yes & 25 & 1 & 4 & 2 & 3 & 35 \\
\hline No & 1 & 1 & 1 & 1 & 3 & 4 \\
\hline Total & 26 & 2 & 5 & 3 & 39 \\
\hline
\end{tabular}

\begin{tabular}{lllllll}
\cline { 2 - 7 } & \multicolumn{2}{l}{ Level of damage suffered } & & & \\
\hline The director is worried & Low & Moderate & Strong & Very strong & Do not know & Total \\
\hline Yes & 11 & $\mathbf{1 4}$ & 5 & 2 & 0 & 32 \\
\hline No & 1 & 3 & 2 & 0 & 1 & 7 \\
\hline Total & 12 & 17 & 7 & 2 & 1 & 39 \\
\hline
\end{tabular}

The directors who are worried that another earthquake will occur again on the Alhama de Murcia fault are those who have put in place a structural prevention measures such as the construction of the building according to the earthquake-resistant standards and the realization of the diagnosis following the last earthquake. It could be expected that the worried directors would 
have suffered major damage and undertook major repairs. Yet the last two cross-tabulations indicate the opposite. Directors who have suffered low and moderate damage, combined with the lack of work or repair, are among the most concerned. Finally, the answers to question 17 are broken down as follows. $71.80 \%$ think that an earthquake of moderate or strong magnitude could damage the institution, against $15.38 \%$ who answered "no" and $12.82 \%$ who could not answer. The worries of directors can be linked with the supposed damage that an earthquake can cause to the institutions (Table 9).

TABLE 9

Cross-tabulation linking the potential damage of an earthquake with the anxiety of the directors

\begin{tabular}{l|lll}
\cline { 2 - 4 } & The director is worried & No & Total \\
\hline Potential damage & Yes & $2(1.49)$ & 28 \\
\hline Yes & $\mathbf{2 6}(1.24)$ & 0 & 5 \\
\hline No & $5(0.89)$ & 2 & 6 \\
\hline Do not know & 4 & 4 & 39 \\
\hline Total & 35 & & \\
\hline
\end{tabular}

The 26 directors, or $66.66 \%$ of the total interviewed, are worried and think that a future earthquake could damage their institution. A correlation could be made between these two factors presented in the table above and the GIVE. For these 66.66\%, we obtain an average GIVE of 1.24 (in parentheses in the table). While for the two institutions, that is $5.12 \%$ of the total sample, the directors who are not worried but think that a future earthquake is likely to cause damage, the average GIVE is 1.49. Although these two GIVE have a moderate value, there is a slight increase for directors who are not worried.

On the other hand, if we compare them with the other five institutions, i.e. $12.82 \%$ for all the institutions, where the directors are worried without assuming the damage of their structure, the GIVE obtained is 0.89 . This suggests that the more worried directors are, the less vulnerable they are. Concern is therefore a determining factor in the calculation of the GIVE, and also in the taking of mitigation measures in the face of the seismic hazard, presented in the following part.

\subsection{PREVENTION METHODS ADOPTED IN EDUCATIONAL INSTITUTIONS}

\subsubsection{Mitigation measures for improved structural resilience}

Regarding the emergency plan, the question 18 is related to question 26 asked later in the questionnaire (Table 10). This makes it possible to know if the director answered the first question correctly. It is recommended that the emergency plan is composed of at least one evacuation plan of the institution and safety instructions to be respected in the event of an earthquake.

TABLE 10

Percentage distribution of answers to closed questions on mitigation measures for improved institutional resilience

\begin{tabular}{llll}
\hline Questions & Yes & No & Do not know \\
\hline 18. Do you have an emergency plan? & 82.06 & 15.38 & 2.56 \\
\hline 20. Are you insured in case of structural damage? & 76.93 & 17.95 & 5.12 \\
\hline $\begin{array}{l}\text { 22. Are the furniture (wardrobe, bookshelf, billboard, etc.) } \\
\text { hung on the walls? }\end{array}$ & 43.59 & 41.03 & $\begin{array}{l}\text { Not all } \\
15.38\end{array}$ \\
\hline $\begin{array}{l}\text { 23. Have you backed up your computer data on external media } \\
\text { (hard disk, USB key, etc.)? }\end{array}$ & 87.18 & 12.82 & 0 \\
\hline $\begin{array}{l}\text { 26. Do you have an evacuation plan and safety instructions to } \\
\text { follow? }\end{array}$ & 89.74 & 10.26 & 0 \\
\hline
\end{tabular}

Note that $82.06 \%$ of directors gave an evacuation plan to their institution, against $15.38 \%$ which do not and $2.56 \%$ which do not know. These respective rates are similar to the results obtained in question 26 , with $89.74 \%$ of correct answers and $10.26 \%$ who have not put in place an evacuation plan or instructions. We also observe that there are more institutions with 
evacuation plans and instructions than there are institutions with an emergency plan. This is because although some directors did not have an emergency plan in place, they did develop a list of safety instructions and an evacuation plan for their institution.

Then, the question 20 relating to the prescription of insurance, $76.93 \%$ of institutions are insured in case of structural damage. Conversely, $17.95 \%$ have not taken out insurance and $5.12 \%$ do not know if they are insured. Among those who do not have insurance, we note that all directors are worried about future earthquakes, except one. They are all in possession of an emergency plan consisting of an evacuation plan and safety instructions, and they belong to the public sector in $85.71 \%$ of cases. They also have a moderate GIVE. Notwithstanding, these factors do not determine whether prescription to insurance is a key element in the overall level of vulnerability for each of these institutions. No relation can be made to the level of study because the percentages of answers seem to be distributed randomly even if a larger number of primary schools is observable, surely explained by the overrepresentation of these compared to the total sample.

Finally, the question 22 reveals that only $43.59 \%$ of institutions hung furniture on the walls, compared to $41.03 \%$ who did not, and $15.38 \%$ who fixed only the largest pieces of furniture. This high percentage of institutions that have not hung objects to the walls reveals insufficient awareness among directors of the risk involved. In fact, $61.54 \%$ of the institutions in the towns of Lorca and Totana combined suffered moderate to very severe damage, corresponding to much more than the falling of objects, if not the opening of deep cracks in the facades or even, the collapse of an entire building in the neighborhood La Viña (Lorca) mentioned above, and also the partial or complete destruction of seven educational institutions. In the event of an earthquake, furniture can become a death trap for $41.03 \%$ of these institutions. As for the computer data, $87.18 \%$ of the directors saved them on an external support, against $12.82 \%$ who did not consider it important the loss of their data.

\subsubsection{Measures to mitigate the vulnerability of teachers and students}

More than half of the directors $(58.97 \%)$ have made no change in their seismic risk management and communication practices in their institution since the disaster (Table 11).

TABLE 11

Percentage distribution of answers to closed questions regarding the resilience of institutions on a human level

\begin{tabular}{llll}
\hline Questions & Yes & No & Do not know \\
\hline $\begin{array}{l}\text { 24. After the earthquake of May 11, 2011, have you made any changes } \\
\text { in your management and communication methods with staff? }\end{array}$ & 33.34 & 58.97 & 7.69 \\
\hline $\begin{array}{l}\text { 28. Have teachers received training on how to respond to seismic hazards } \\
\text { (methods of protection and evacuation, decision-making)? }\end{array}$ & 35.90 & 64.10 & 0 \\
\hline 29. Are responsible designated during an earthquake? & 66.67 & 30.77 & 2.56 \\
\hline 30. Do you organize simulation and evacuation exercises? & 74.35 & 25.65 & 0 \\
\hline $\begin{array}{l}\text { 32. Have you provided teachers and students with a survival kit (first aid } \\
\text { kit, food bars, flashlights, thermal blankets, radio, etc.)? }\end{array}$ & & 92.69 & 0 \\
\hline 33. Do you know of any refuge areas in the town? & 28.20 & 71.80 & 0 \\
\hline
\end{tabular}

A more precise analysis of the levels of damage suffered by institutions that have not made any changes shows that they are the ones that suffered the greatest damage (Table 12). 
TABLE 12

Cross-tabulation linking the changes in the management and communication method and the damages suffered during the earthquake of May 11, 2011

\begin{tabular}{lllllll}
\cline { 2 - 7 } & \multicolumn{2}{l}{ Level of damage suffered } & & & Total \\
\hline Changes & Low & Moderate & Strong & Very strong & Do not know & 13 \\
\hline Yes & 3 & 6 & 3 & 0 & 1 & 23 \\
\hline No & 9 & 6 & 4 & 2 & 0 & 3 \\
\hline Do not know & 0 & 3 & 0 & 0 & 3 & 39 \\
\hline Total & 12 & 15 & 7 & 2 & 3 & 2 \\
\hline
\end{tabular}

In fact, among all these institutions, the only ones that have suffered a great deal of damage are those that have not made any improvement to their management and communication.

The answers to question 28 show that training teachers to respond to seismic risk is not a priority for $64.10 \%$ of directors. Despite this, teacher training on methods of protection and evacuation, and proper decision-making during an earthquake, seems to be paramount. The teacher is usually the only person in contact with the students from the onset of earthquakes, and is therefore naturally responsible until the authorities and take over. However, we note that in $66.67 \%$ of cases, responsible are designated in case of earthquake. During an interview with the director of a high school in Lorca, he said that a responsible is designated on each floor of the institution. After the evacuation of students and staff, they are responsible for checking whether people have remained in classrooms, corridors, stairs, canteen, etc. Although the rate of appointment of responsible is not high, $74.35 \%$ of schools set up simulation and evacuation exercises at least once in the school year. Indeed, it is a regulatory obligation in the same way as the evacuation drills. This allows students and teachers to realize that seismic risk is perpetually present, and that it is necessary to know in all circumstances the best behavior to adopt to limit the number of victims. One of the school heads of Lorca said in an interview that a method was adopted in his high school, different from what we could currently know. "I want to be able to sleep peacefully knowing that I have 1000 students in my charge. The students themselves organize evacuation drills under the supervision of the person in charge of natural and professional risks". As a result, students feel more confident because by getting involved at this level of prevention, they learn the right gestures. This automatism is necessary to save lives.

With regard to question 32, the majority of institutions do not have survival kits, i.e. $92.31 \%$. This kit is necessary in case of unforeseen emergency. A frequently asked question during interviews is: how can we conserve food? It is advisable to have food bars based on wheat plant, vegetable fats and sugars, because they are of high caloric value and have a lifespan of five years, according to the Ris'K website.

Finally, question 33 concerning the knowledge of a refuge area in the town of Lorca or Totana, $71.80 \%$ of the directors answered that they did not know any one, against $28.20 \%$ who did not know but they have determined themselves refuge areas. Indeed in 2015 the towns of Lorca and Totana have still not defined safe areas.

\subsection{BEHAVE DURING AN EARTHQUAKE}

Regarding the best behavior to adopt from the onset of the first earthquakes, the most cited answer, at $92.3 \%$, was to take refuge under a table and maintain it (Table 13). The second most checked answer, $66.66 \%$, was to place oneself in the frame of a door. We also note that the closure of the gas network is not a priority because only $35.89 \%$ of the directors checked this answer. Although a significant percentage of institutions, 33.34\%, answered this question correctly, $5.12 \%$ answered "go out running" and $2.56 \%$ did not know what to answer. 
TABLE 13

Frequency of answer to the multiple-choice question $n^{\circ} 35$ concerning the best behavior to adopt from the first seconds

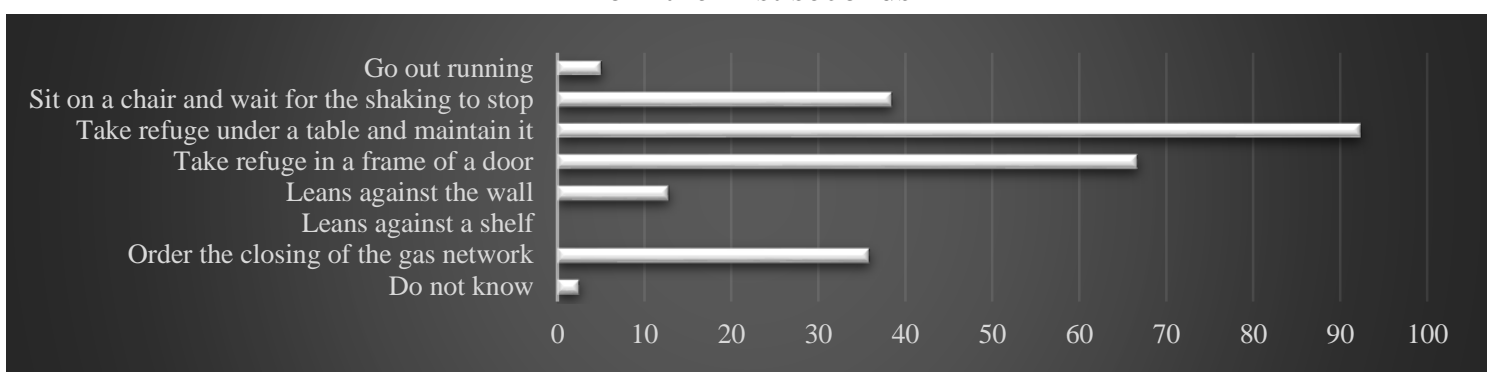

Finally, over the entire sample, $12.82 \%$ of respondents chose the answer "lean against the wall". This behavior is valid only in the case where it is impossible to take shelter under solid furniture or in the frame of a door, and if the wall is thick and built to the seismic standards and no object is hanging on the wall or on the ceiling. In the studied institutions, the walls are mainly partitions which resist very little to the movements of the ground, so it is advisable to lean only to the bearing walls and the pillars. As mentioned above, $33.34 \%$ of the institutions were assigned a vulnerability index 0 , because they chose taking refuge under a table and maintain it, stand in the doorway and order the closing of the gas network. A larger proportion of institutions, $41.02 \%$, had a vulnerability index 1 . Then, $20.52 \%$ of the institutions have a vulnerability index 2 . Finally, the vulnerability index 3 was assigned to $5.12 \%$ of institutions.

It was therefore asked whether, after the tremors, the directors knew the most effective method of evacuating their school (Table 14). During the first earthquake of 2011, people remained confined inside the buildings thinking that they were safe from danger, and left a few minutes before the second earthquake. When this happened, most of the buildings were badly damaged and left many people still dead on the street.

TABLE 14

Percentage of answers to multiple choice question 36 regarding the most effective method of evacuating the educational institution

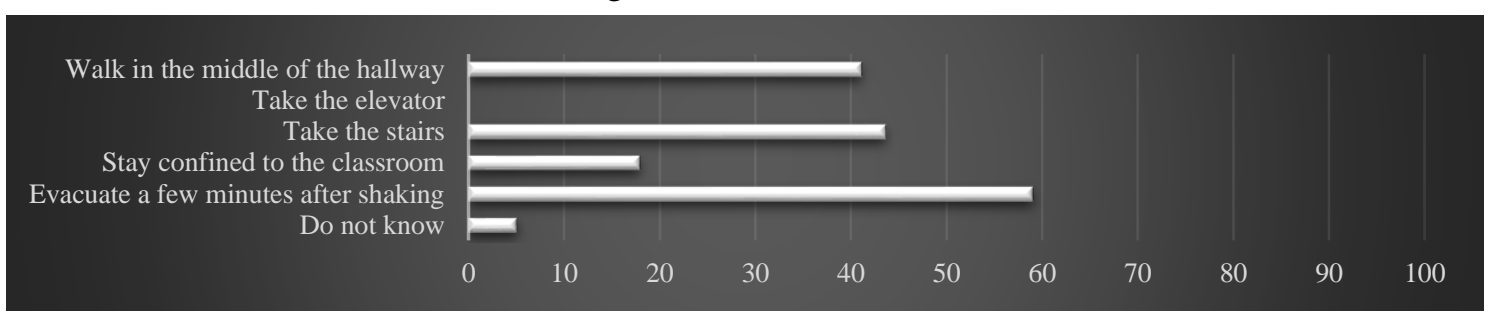

Thus, one of the proposed answers, namely: staying confined to the classroom, was chosen in $17.94 \%$ of cases. On the other hand, $58.97 \%$ of the directors felt it was more appropriate to evacuate a few minutes after the shaking. It is a kind of confirmation of the lack of information on the part of the authorities. After experiencing an earthquake some years ago, the total sample should be aware of the need to evacuate in the event that replicas of greater magnitude and intensity occur, as was the case in 2011 . Then, we note that only $43.58 \%$ of the institutions answered that it was necessary to go down the stairs, and $41.02 \%$ to walk in the middle of the corridor. Again, we find that institutions are poorly informed about evacuation methods. No institution answered that it was necessary to take the elevator, which is a positive point but $5.12 \%$ could not answer.

After the evacuation of the building, the next step is to adopt a correct behavior outside (Table $15)$. 
TABLE 15

Percentage of answers to question 37 regarding the most effective method of evacuating the educational institution

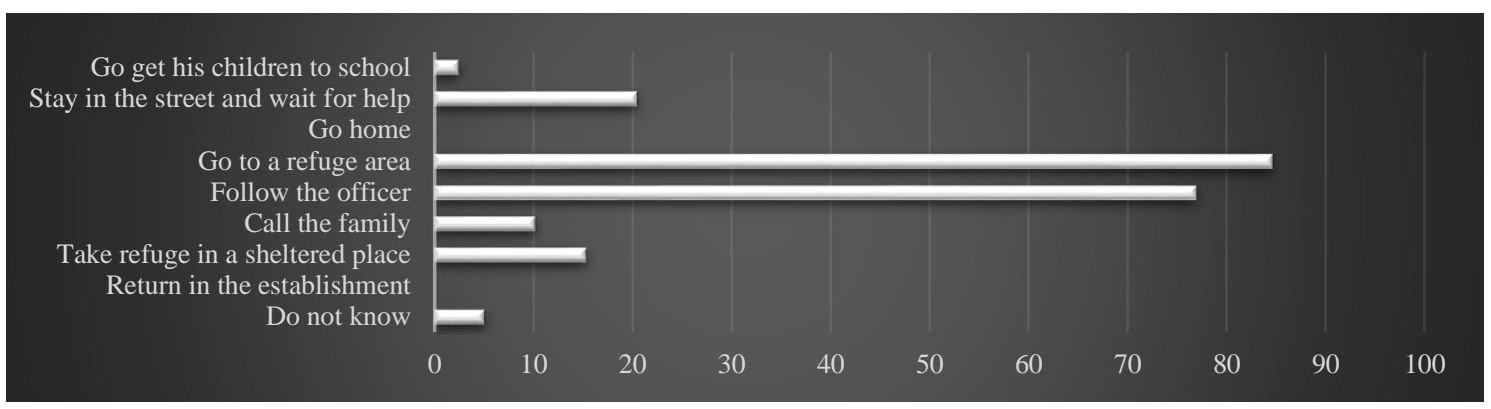

$84.61 \%$ of the directors answered that they had to go to a secure area and in second choice, to $76.92 \%$, follow the responsible designated at the beginning school year. $20.51 \%$ of the total choose to stay on the streets and wait for help. This percentage is high and it is inadvisable to stay on the street because walls can fall. Another behavior to avoid is to take refuge in a sheltered place $(15.38 \%)$ because replicas of higher intensity can cause more damage. Another reflex to not have is to get his own children to school $(2.56 \%)$ and call his family $(10.25 \%)$ to avoid the collapse of telephone lines. A small proportion of directors, i.e. $2.56 \%$, were unable to answer this question. None of the directors replied that they had to go back to the institution to pick up personal belongings or go home, which is still encouraging.

As a final point, a last closed and multiple-choice question about how to behave on a secure area offered only four correct answers (Table 16).

TABLE 16

Percentage of answers to question 38 concerning the best behavior to adopt on a secure area

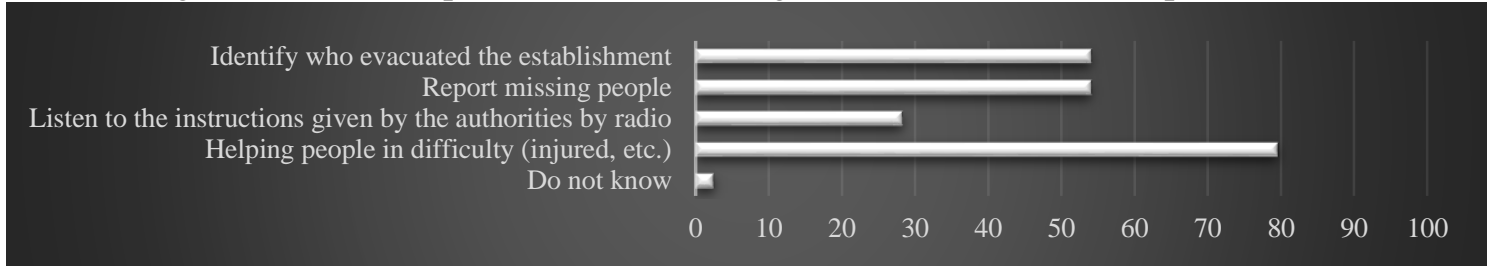

The aim was for the directors to check all the answers. However, we note that the most frequently quoted answer, $79.48 \%$ is to help people in difficulty. Then, equally, $53.84 \%$ of the directors chose the census of the people who evacuated the building and report missing people. Listening to instructions given by the authorities by radio seems to be less of a priority, i.e. $28.20 \%$. Finally, $2.56 \%$ did not know what answer to give.

The index 0 was assigned to the directors who checked all the answers, i.e. $20.52 \%$. Indexes 1 and 2 were obtained in equal parts, i.e. $33.33 \%$. Finally, $12.82 \%$ of the institutions have an index 3.

\section{THE RESULTS OF THE VULNERABILITY}

\subsection{THE HUMAN VULNERABILITY INDEX}

Considering all educational institutions (39) in the towns of Lorca and Totana, without any difference, we note that the Human Vulnerability Index is mostly moderate. The rate is $64.10 \%$ of the total institutions interviewed. A moderate index means that institutions take into consideration the prevention and protection of their occupants, students, teachers and staff, without making it a priority. In other words, these institutions have put in place the most minimalist measures to respond to an earthquake, namely: an emergency plan which consists of at least one evacuation plan and safety instructions, and the organization of at least one earthquake-specific simulation exercise during the school year. The value of this index is $61.54 \%$ 
of the total institutions of Lorca against $69.23 \%$ for the institutions of Totana, i.e. 7.69 points of difference. It can be concluded that human vulnerability has been better taken into account in Lorca since the 2011 earthquake.

The low Human Vulnerability Index corresponds in this case to institutions where the prevention and protection are a priority. They rank second with $28.20 \%$ of the total sample. This rate seems encouraging regarding the frequency of appearance of earthquakes in the region, but on the other hand, it may seem discouraging because years after the disaster, the part of wellprepared institutions to seismic risk is not a majority. However, their prevention system is much more sophisticated than institutions with moderate vulnerability, which enables them to respond adequately in an emergency.

In addition, the high Human Vulnerability Index accounts for $7.69 \%$ of all institutions interviewed. The high vulnerability index could also be expected to be much higher for the institutions of Totana, given that the last major earthquake of that town dates back to 1921 . However, this index is even for both towns. Although a small percentage, it represents a significant proportion of institutions with little or no preparedness in the event of a disaster. Thus, the theme of prevention against seismic risk is not a priority. One of the most concrete and disturbing examples is an institution located in the town of Totana which has not put in place any protection or system of prevention against earthquakes and the director's words were "During an earthquake the only thing to do is to rush outward". Proof that this person does not know in any case the best behavior to adopt in this situation.

\subsection{THE STRUCTURAL VULNERABILITY INDEX}

With regard to the Structural Vulnerability Index, the moderate index is much smaller than the Human Vulnerability Index. The percentage of educational institutions with a moderate index is $35.90 \%$ compared to the total of the sample. Thus, more than one third of the institutions have invested in setting a minimum required to reach a resilience phase after a disaster. The realization of a diagnosis of the building following the earthquake of May 11, 2011 made it possible to know the state of the structure and to determine if repair works were necessary. This has also resulted in the safeguarding of computer data on an external medium such as a USB key or an external hard disk, and the prescription for insurance in case of structural damage.

The low Structural Vulnerability Index stands out with a rate of $58.98 \%$ or 23.08 points higher than the index of moderate value. An important part of institutions have taken sufficient steps to reduce their vulnerability and thus be structurally prepared to deal with an earthquake. For the town of Lorca, it is no longer a moderate index of vulnerability that predominates but a low vulnerability index. There are more institutions that are well prepared in the event of an earthquake than institutions that are little or moderately prepared, i.e. that have made available to them the minimum required, on the structural plan. At the same time, the percentage of Totana institutions with moderate vulnerability is higher than Lorca.

However, 5.12\% of institutions disclose a high Structural Vulnerability Index which is not subject to amnesty considering that the seismic activity in the region of Murcia is important. An earthquake can occur at any time and damage the structure, as was the case for six educational institutions, whose structure was partially rebuilt or demolished for a complete rebuilding, after suffering significant damage.

\subsection{THE GLOBAL INDEX OF VULNERABILITY TO EARTHQUAKE (GIVE)}

The Human and Structural Vulnerability Indexes result in a mainly moderate trend GIVE. In other words, $64.10 \%$ of the total number of educational institutions surveyed put in place the bare minimum in terms of prevention, as mentioned earlier. Conversely, only $35.90 \%$ of the sample are really ready for seismic risk. Even though the towns of Lorca and Totana have a Human Vulnerability Index that is similar at first glance, their Structural Vulnerability Index plays a big role in the calculation of the GIVE of each institution. A larger proportion of institutions with a low index are in the town of Lorca and a larger proportion of institutions with a moderate index are in the town of Totana (Figure 5). 
FIGURE 5

Geographic localization per institution according to Human Vulnerability Index (top left), Structural Vulnerability Index (top right) and Global Index of Vulnerability to Earthquake (middle)

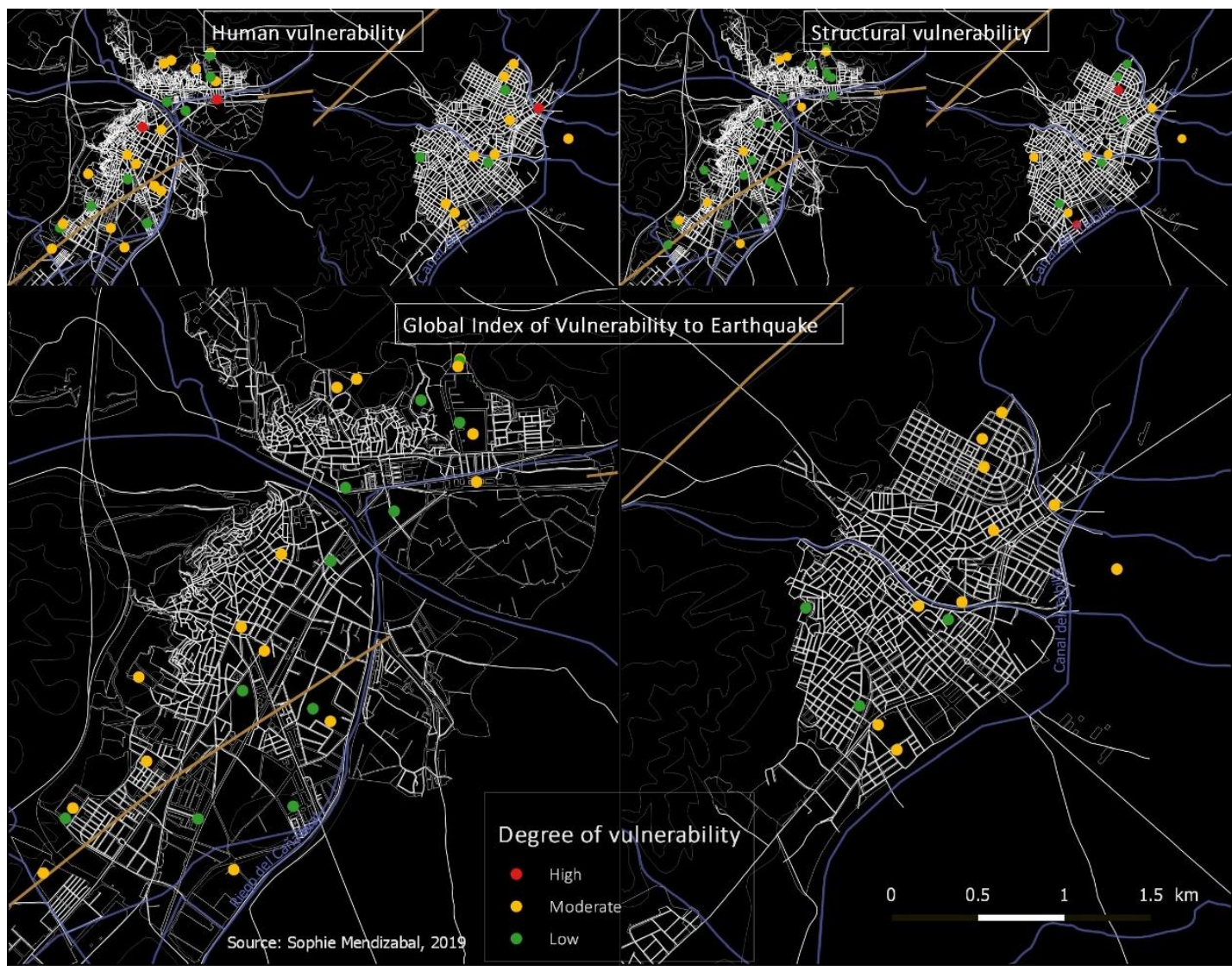

Source: Sophie Mendizabal, 2019

To conclude on the perception of risk in general, a relatively large proportion of educational institutions, whether for the town of Lorca or Totana, is moderately vulnerable. The educational institutions of Totana have a slightly higher vulnerability. This can be explained by Lorca has recently experienced an earthquake recently unlike Totana. Although the last major earthquake was in 2011, the institutions do not have sufficient preparedness to deal with a new disaster. An explanation could be given, namely, a certain lack of information from the authorities on the seismic risk and the methods of prevention and protection. The most striking example concerns a problem of information and communication to the population. Indeed, many directors interviewed mentioned that during the 2011 earthquake, "the information given by radio was contradictory. The authorities kept saying that another earthquake was going to happen. The only thing they managed to do was scare the people. Nobody knew what to do" according to the director of a Lorca institution. Indeed, "unpredictable urban and technical dysfunctions mean the temporary or lasting blockage of communication [...] networks [...] causing panic, the disruption of the mass media and therefore the ambiguous nature of the warning and evacuation messages. They often result in the confusion of neighborhood communities and subsequently the disruption of local decision-making relays" " (THOURET et al., 1996).

\footnotetext{
2 Translated version from the original text. "Les dysfonctionnements urbains et techniques imprévisibles désignent le blocage temporaire ou durable des réseaux [...] de communication [...] provoquant la panique, la désorganisation des mass médias et donc le caractère équivoque des messages d'alerte et d'évacuation. Ils entraînent souvent la décohésion des communautés des quartiers et par la suite l'interruption des relais de décision locaux. » (THOURET et al., 1996)
} 
Another important gap to mention is the absence of official refuge areas in the towns of Lorca and Totana. "The authorities need to be more serious in the face of a disaster. It is hard to believe that nothing is yet planned for a new earthquake. We are still in the same situation as in 2011" according to a director of Lorca. Also, the fact that there is "no feeling of danger" plays a role of major importance. The level of vulnerability is largely due to the information provided to educational institutions. Awareness is a key factor in the process of reducing the propensity to damage in case of seismic risk. According to THOURET et al (1996), a concrete prevention policy accompanied by the education of school populations should enable schools to quickly reach a threshold of sufficient awareness. For this, a proposal for refuge areas in both towns was made following a sufficient distance from the buildings to prevent any fall of facades (Figure 6).

FIGURE 6

Proposal of localization of refuge areas in Lorca and Totana

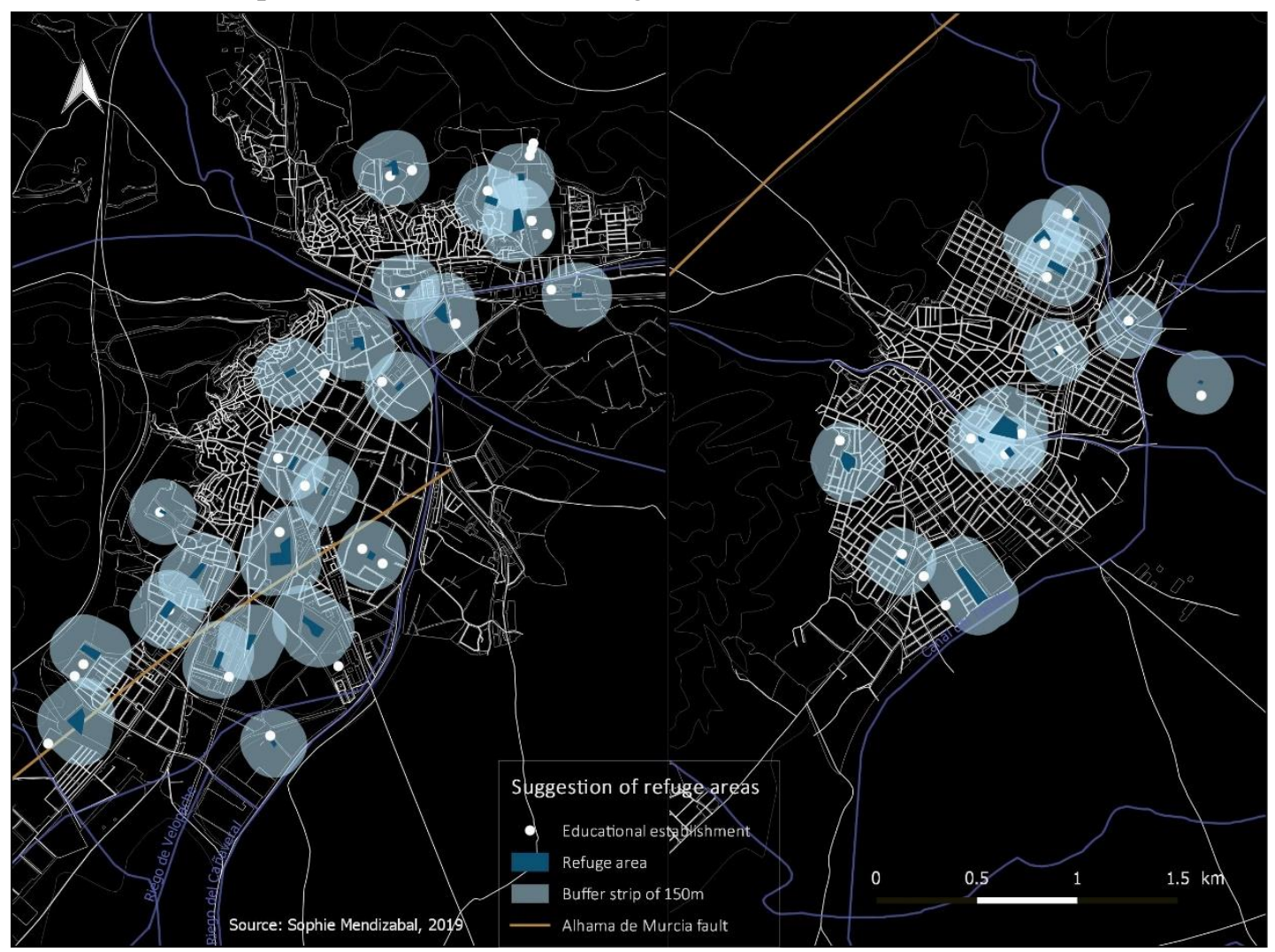

Source: Sophie Mendizabal, 2019

\section{CONCLUSION}

This comparative study on the vulnerability of educational institutions in the towns of Lorca and Totana highlights a chronic fragility in the prevention and protection against seismic risk, in human and structural terms. The results show that greater importance is given to structural protection. 58.98\% of institutions have a low Structural Vulnerability Index compared to $28.20 \%$ with a low Human Vulnerability Index.

Highlighting the strengths and weaknesses of the education sector reveals the need to improve the system of protection against seismic risk. Institutions are mostly unable to cope with a major earthquake. Since the directors have adopted the smallest prevention and protection measures for $64.10 \%$ of them, it is difficult to predict resilience under good conditions. Moreover, the weakness of this sector does not derive directly from the institutions but rather from the authorities. Indeed, there is a growing demand from the directors for additional information on seismic risk.

Four years after the disaster, gaps in prevention and seismic risk management are strongly perceived. However, an earthquake with a magnitude between 6 and 7 is expected on the Alhama 
de Murcia fault. So many improvements are to be made. On the one hand, with regard to the information transmitted during an earthquake and, on the other hand, the creation of refuge areas close to the institution. The aim would therefore be to reduce human vulnerability through preventive information and actions destined to prepare the population by transforming the acceptance of the damage into an awareness of the effective protection measures.

To finish, it would be interesting to do again this study in 2021, ten years after the earthquake, to see the improvements made in the seismic risk management and compare with the results of 2015. As long as these two towns do not operate a high-quality prevention, the seismic risk will cause very serious damage. For this, it is essential to call on professionals in the prevention and management of natural hazards because in 2015, shaking continued in the hearts of the inhabitants.

\section{ACKNOWLEDGEMENTS}

I am grateful for the kindness and availability of all directors of educational institutions of the towns of Lorca and Totana for giving me interviews in their busy agenda as well as Sofía González López, the head of the Civil Protection of the region of Murcia. I also thank PhD Antonio M. Rico Amorós, director of Instituto Interuniversitario de Geografía of the University of Alicante, Spain, and PhD Alfredo Ramon Morte, director of the Laboratory of Geomatic Science of the University of Alicante.

\section{REFERENCES}

BENITO OTERINO, B., RIVAS MEDINA, A., GASPAR-ESCRIBANO, J.M., MURPHY, P. (2012): El terremoto de Lorca (2011) en el contexto de la peligrosidad y el riesgo sísmico en Murcia. Física de la Tierra 24:255-287

BSSC (Building Seismic Safety Council) (2006): Earthquake-resistance requirements. In: FEMA 232, Homebuilders' Guide to Earthquake Resistant Design and Construction, $2^{\text {nd }}$ edition, Washington D.C. 21-48

CAPOTE, R., ESTÉVEZ, A., SANTANACH, P., SANZ DE GALDEANO, C., SIMÓN, J.L. (2011): ¿Dónde y por qué se producen terremotos en la península ibérica? Enseñanza de las Ciencias de la Tierra 19.3:317-328.

CERVERA, J. (2012): Dynamique des structures. Vulnérabilité aux bâtiments. Construction parasismique. Centre d'Innovation en Technologie pour le Développement Humain. Université Polytechnique de Madrid, 75 p.

GUHA-SAPIR, D., HOYOIS, P., WALLEMACQ, P., BELOW, R. (2016): Annual Disaster Statistical Review 2016. The numbers and trends. Centre for Research on the Epidemiology of Disasters (CRED), Institute of Health and Society (IRSS), Université catholique de Louvain, Brussels, Belgium

SALCEDO HERNÁNDEZ, J.C., CAMPESINO FERNÁNDEZ, A.J. (2012): Experiencias constructivas del terremoto de Lorca. Investigaciones geográficas 57:7-37

THOURET, J.C., D'ERCOLE, R. (1996): Vulnérabilité aux risques naturels en milieu urbain : effets, facteurs et réponses sociales. Cahiers des Sciences Humaines 96-2:407-422

VISSERS, R.L.M., MEIJNINGER, B.M.L. (2011): The 11 May 2011 earthquake at Lorca (SE Spain) viewed in a structural-tectonic context. Solid Earth 2:199-204 